\title{
Evaluation of in vitro and in vivo therapeutic efficacy of Ribes alpestre Decne in Rheumatoid arthritis
}

\author{
Alamgeer Umme Habiba Hasan ${ }^{\circledR 1}$ \\ ${ }^{1}$ Laboratory of Cardiovascular Research and Integrative Pharmacology, Department of Pharmacology, College of Pharmacy, \\ University of Sargodha, Sargodha, Pakistan
}

\begin{abstract}
Rheumatoid arthritis is an autoimmune inflammatory disorder, despite the discovery of numerous drugs there is still need to introduce newer, safer and more effective sources of drugs such as medicinal herbs. Present research work was an attempt to appraise the antiarthritic potential of Ribes alpestre Decne in rheumatoid arthritis. In vitro inhibition of protein (bovine serum albumin and egg albumin) denaturation, Human red blood cell membrane stabilization assays along with formaldehyde induced arthritis in rats were commenced in this study. Findings of present investigation demonstrated significant and dose dependent antiarthritic effect of Ribes alpestre. Aqueous ethanolic extract, butanol and aqueous fraction illustrated $95 \%, 69.233 \%$ and $92.840 \%$ protection at $6400 \mathrm{ug} / \mathrm{mL}$ against bovine serum albumin denaturation respectively. Similarly, plant extract together with butanol and aqueous fractions showed $3653.47 \%, 1484.03 \%$ and $3563.19 \%$ inhibition of pathological alteration of egg albumin in that order. Moreover, hydroethanolic extract with butanol and aqueous fraction exhibited $91.29 \%, 65.73 \%$ and $89.62 \%$ stabilization against erythrocyte hemolysis at $6400 \mathrm{ug} / \mathrm{mL}$ correspondingly. Furthermore, hydroethanolic extract, butanol and aqueous fraction notably $73.49 \%, 66.42 \%$ and $68.87 \%$ decreased paw edema at highest dose $(200 \mathrm{mg} / \mathrm{kg})$. Similarly aqueous ethanolic extract, butanol and aqueous fraction illustrated $72.38 \%, 54.90 \%$ and $66.33 \%$ decrease in paw thickness at $200 \mathrm{mg} / \mathrm{kg}$. Hence results suggested that Ribes alpestre possess antiarthritic potential thus supporting its use as natural remedy in rheumatic conditions.
\end{abstract}

Keywords: Arthritis. Ribes alpestre. Protein denaturation. Membrane stabilization. Formaldehyde.

\section{INTRODUCTION}

RA is a multifactorial polygenic inflammatory disease accompanied by synovitis, progressive destruction of cartilage and bone in numerous joints, physical disability, systemic manifestations and untimely mortality. Although exact pathogenesis of rheumatoid arthritis remains to be fully elucidated, but a key facet is linkage between an array of inflammatory cells, particularly macrophages, T lymphocytes and cells residing in synovial cavity (Kay, Calabrese, 2004). In the long term management of such chronic inflammatory disorders various classes of drugs including NSAIDs, DMARDs, steroids and biologicals have been used, as there is no doubt about the ability of these drugs to effectively relieve pain, inflammation and lessen cartilage as well as bone

\footnotetext{
*Correspondence: Laboratory of Cardiovascular Research and Integrative Pharmacology, Department of Pharmacology, College of Pharmacy, University of Sargodha, Sargodha, Pakistan. Email: alam_yuchi@yahoo.com
}

deterioration. But downside is that all of these drugs can provoke severe side effects, mainly in the gastrointestinal (e.g. ulceration) and renal (e.g. tubular necrosis) systems, myocardial infarction, stroke, malignancies and high risk of infections. Besides new frontiers in human research for knowledge, there are still cluster of anonymities surrounding human physiology and chemistry which science is yet to be discovered. Medicinal plants have been found as the major source of active principles capable of curing diseases and maintaining good health through indigenous knowledge (Nwachukwu, Umeh, Kalu, 2010). Nonetheless, medicinal plants owe their importance as prestigious therapeutic modalities in human civilization since archeological find (Khan et al., 2011). Ribes alpestre Decne commonly known as ShumLooh belongs to Grossulariaceae family. Roots and fruits of this plant are used medicinally in Khunjerab national park, Gilgit, Pakistan. Root powder is used for the backache and joint pain whereas, fruit is supposed to be a remedy for the 
Jaundice (Khan et al., 2011; Abbas et al., 2014). Hence the main intent of current study is to scientifically support folkloric use of this plant in the treatment of rheumatism among local inhabitants.

\section{MATERIAL AND METHODS}

\section{Plant collection}

Roots of Ribes alpestre Decne were collected from Gilgit Baltistan and was further identified and authenticated by Dr. Shair Wali Khan, Assistant Professor Botany, Karakorum International University Gilgit Baltistan Pakistan. Voucher specimen (RA-17-10) was stored in herbarium of College of Pharmacy, University of Sargodha for future reference.

\section{Preparation of extract and fractions}

Dried and pulverized roots of Ribes alpestre were macerated and extracted with $12 \mathrm{~L}$ of $70 \%(\mathrm{v} / \mathrm{v})$ aqueous ethanol mixture for three days at room temperature (23$25{ }^{\circ} \mathrm{C}$ ) with intermittent shaking followed by filtration through cotton cloth and afterwards via Whatman filter paper no.1. This soaking and filtration process was repeated two times more and then all the filtrates were combined and solvent was removed under vacuum by rotary evaporator $\left(40-50{ }^{\circ} \mathrm{C}\right)$. Resultant plant extract was further air dried producing thick pasty mass with yield of (7.36\%) (Alamgeer et al., 2017). Crude extract (80 g) was further fractionated by sequential solvent partition using various organic solvents including n-hexane, dichloromethane, ethylacetate and n-butanol. N-hexane, dichloromethane, and ethylacetate fractions were obtained in very low quantity as their yield was $4.85 \%, 2.06 \%$, $3.25 \%$ respectively while butanol $(21.01 \%)$ and aqueous fractions $(66.19 \%)$ were of sufficient quantity to carry out all experimental procedures. Distilled water was used to made test solutions for all in vitro and in vivo experimental activities.

\section{Animals}

Sprague-Dawley rats (200-300g) were used and they were housed in standard environmental conditions and fed with standard rodent diet with water ad libitum. All animal procedures were followed in accordance with the approved protocol for use of experimental animals set by the standing committee on animals at Department of Pharmacology, College of Pharmacy, and University of Sargodha.

\section{Drugs and chemicals}

Formaldehyde (VWR, International Ltd, England), Diclofenac sodium (Sigma-Aldrich, USA), aspirin (UniChem, Germany), bovine serum albumin (Sigma-Aldrich, USA), egg albumin from fresh hen's egg, $n$-butanol (Sigma-Aldrich, USA), ethylacetate (Sigma-Aldrich, USA), hexane (Sigma-Aldrich, USA), dichloromethane (Sigma-Aldrich, USA), sodium chloride (SigmaAldrich, USA), disodium hydrogen phosphate (Merck, Germany), ethanol, potassium dihydrogen phosphate (Riedel-de-Haen, USA), sodium hydroxide (SigmaAldrich, USA), hydrochloric acid (Riedel-de-Haen, USA) were used.

\section{Inhibition of protein denaturation using Bovine serum albumin}

$0.5 \mathrm{~mL}$ reaction mixture of various concentrations consisting of $0.45 \mathrm{~mL}$ bovine serum albumin $(5 \%$ aqueous solution) and $0.05 \mathrm{~mL}$ of $70 \%$ ethanolic extract/ fractions of Ribes alpestre Decne along with aspirin were prepared. $\mathrm{pH}$ was calibrated at 6.3 using $1 \mathrm{~N} \mathrm{HCl}$. After preparation mixtures were incubated at $37^{\circ} \mathrm{C}$ for $20 \mathrm{~min}$ subsequently heating at $57^{\circ} \mathrm{C}$ for $30 \mathrm{~min}$. After cooling the samples, $2.5 \mathrm{~mL}$ phosphate buffer saline ( $\mathrm{pH}$ 6.3) was added to each test tube. Moreover, $0.05 \mathrm{~mL}$ distilled water was used in place of plant extract/fractions in control test tube whilst product control did not contain bovine serum albumin. In due course, absorbance was measured spectrophotometrically at $660 \mathrm{~nm}$ and percentage inhibition of protein denaturation was calculated as follows (Alamgeer, Uttra, Hasan, 2017)

$\%$ age inhibition $=\frac{100-(\text { Abs. of Ts }- \text { Abs. of PC })}{\text { Abs. of TC }} \times 100$

\section{Inhibition of protein denaturation using Fresh hen's egg albumin}

$5 \mathrm{~mL}$ reaction mixture containing $0.2 \mathrm{~mL}$ fresh egg albumin, $2.8 \mathrm{~mL}$ phosphate buffered saline of $6.4 \mathrm{pH}$ and $2 \mathrm{~mL}$ of crude extract/fractions solutions of different concentrations were prepared. Furthermore, similar volume of doubled distilled water was taken as control. Reaction mixture was placed at $37 \pm 2{ }^{\circ} \mathrm{C}$ in incubator for 15 minutes followed by heating at $70{ }^{\circ} \mathrm{C}$ for $5 \mathrm{~min}$. After cooling, absorbance was taken at $660 \mathrm{~nm}$ by using vehicle as a blank. Likewise, diclofenac sodium at same concentrations served as standard control and absorbance 
was measured afterwards. Percentage inhibition of protein denaturation was calculated by using the following formula:

$$
\% \text { of inhibition }=100 \mathrm{X}[\mathrm{Vt} / \mathrm{Vc}-1]
$$

where, $\mathrm{Vt}=$ absorbance of test sample, $\mathrm{Vc}=$ absorbance of control (Alamgeer et al., 2015).

\section{Human red blood cell (HRBC) membrane stabilization}

$0.8 \mathrm{~g}$ sodium citrate, $2 \mathrm{~g}$ dextrose, $0.05 \mathrm{~g}$ citric acid and $0.42 \mathrm{~g}$ sodium chloride dissolved in distilled water with final volume made up to $100 \mathrm{~mL}$ was served as Alservers solution. Moreover, hypotonic saline was prepared by dissolving $0.36 \mathrm{~g}$ of sodium chloride in $100 \mathrm{~mL}$ distilled water. While, isotonic saline was formulated by dissolving $0.85 \mathrm{~g}$ of sodium chloride in of $100 \mathrm{~mL}$ distilled water. Whereas, $0.19 \mathrm{~g}$ of potassium dihydrogen phosphate and $2.38 \mathrm{~g}$ disodium hydrogen phosphate and $8 \mathrm{gm}$ of sodium chloride in $100 \mathrm{~mL}$ of distilled water was taken as Phosphate buffer saline (pH 7.4, 0.15 M).

Blood sample was taken from healthy human volunteers who had not taken any NSAIDs for 2 weeks prior to the experiment and was mixed with equal volume of sterilized Alsevers solution. Subsequently, blood solution was centrifuged at $3000 \mathrm{rpm}$ and the packed cells were separated. Separated packed cells were washed with iso-saline solution and $10 \% \mathrm{v} / \mathrm{v}$ suspension was prepared with isosaline for further use.

$1 \mathrm{~mL}$ of phosphate buffer, $2 \mathrm{~mL}$ of hypotonic saline, $0.5 \mathrm{~mL}$ of crude extract/fractions at various concentrations and $0.5 \mathrm{~mL}$ of $10 \% \mathrm{w} / \mathrm{v}$ human red blood cells were used as test solution. $1 \mathrm{~mL}$ phosphate buffer, $2 \mathrm{~mL}$ water and $0.5 \mathrm{~mL}$ of $10 \%$ human red blood cell suspension in isotonic saline was used as test control. $1 \mathrm{~mL}$ phosphate buffer, $2 \mathrm{~mL}$ hypotonic saline, $0.5 \mathrm{~mL}$ standard drug solution of varying concentration and $0.5 \mathrm{~mL}$ of $10 \% \mathrm{w} / \mathrm{v}$ human red blood cells were taken as standard solution (diclofenac sodium). All the assay mixtures were incubated at $37{ }^{\circ} \mathrm{C}$ for $30 \mathrm{~min}$ and centrifuged at $3000 \mathrm{rpm}$ and supernatant was poured and hemoglobin content was estimated by a spectrophotometer at $560 \mathrm{~nm}$. Percentage protection against hemolysis was estimated by using the following formula (Alamgeer, Uttra, Hasan, 2017).

Percentage protection $=100-[$ (optical density sample $/$ optical density control $) \times 100]$

\section{Formaldehyde induced arthritis in rats}

Sprague Dawley rats of either sex were segregated into different groups with 5 rats in each group. Group I received distilled water $(3 \mathrm{~mL} / \mathrm{kg})$ and taken as diseased control group. While, group II was treated with piroxicam at $10 \mathrm{mg} / \mathrm{kg}$. Group III, IV and V were treated with crude extract at 50, 100 and $200 \mathrm{mg} / \mathrm{kg}$ dose respectively. Furthermore, group VI, VII and VIII were administered butanol fraction at 50,100 and $200 \mathrm{mg} / \mathrm{kg}$ in that order. Similarly, group IX, X and XI were given aqueous fraction at same doses as given above. All treatments were given orally for 10 days respectively. Chronic non-immunological arthritis was induced by subplanter injection of $0.1 \mathrm{~mL}$ of $2 \%$ formaldehyde solution on day $1^{\text {st }}$ 30 min after drug administration and then repeated on day $3^{\text {rd }}$. Arthritis was evaluated by measuring paw diameter and paw volume of rats in all groups at substitute days during a period of 10 days by means of digital vernier calliper and digital plethysmometer accordingly (Alamgeer et al., 2017).

Percentage inhibition of paw edema was calculated using following formula:

Percentage inhibition of edema $=(1-\mathrm{Vt}) / \mathrm{Vc} \times 100$

where, Vt and Vc are the joint diameter of treated and control rats

\section{Statistical analysis}

Data were reported as mean \pm SEM and were analyzed statistically by two-way ANOVA followed by Bonferroni multiple comparison Post hoc test. Values of $\mathrm{p}<0.05$ are regarded as significant.

\section{RESULTS}

Effects of aqueous ethanolic extract of Ribes alpestre alongwith butanol and aqueous fractions on protein denaturation are shown in Table I and II. Crude extract has exhibited significant and concentration dependent $(50-6400 \mathrm{ug} / \mathrm{mL})$ inhibition of protein denaturation with $95 \%$ effect at $6400 \mathrm{ug} / \mathrm{mL}$ regarding bovine serum albumin. Whereas, $\mathrm{n}$-butanol and aqueous fraction showed $65.233 \%$ and $92.840 \%$ blockade against heat induced structural modifications in bovine serum albumin protein. Likewise aspirin revealed $80.586 \%$ inhibition of protein denaturation.

Similarly, ethanolic (70\%) extract of Ribes alpestre considerably prevented $3653.47 \%$ denaturation of egg 
TABLE I - Effect of Ribes alpestre on inhibition of protein (bovine serum albumin) denaturation

\begin{tabular}{|c|c|c|c|c|c|c|c|c|}
\hline \multicolumn{9}{|c|}{$\begin{array}{c}\text { Percentage protection against protein denaturation } \\
\text { Concentration }(\mathrm{ug} / \mathrm{mL}) \\
\end{array}$} \\
\hline $\begin{array}{l}\text { Treatment } \\
\text { Groups }\end{array}$ & 50 & 100 & 200 & 400 & 800 & 1600 & 3200 & 6400 \\
\hline Aspirin & $\begin{array}{c}62.44 \pm \\
0.558\end{array}$ & $\begin{array}{c}64.66 \pm \\
0.461\end{array}$ & $\begin{array}{c}66.59 \pm \\
0.391\end{array}$ & $\begin{array}{c}69.33 \pm \\
0.463\end{array}$ & $\begin{array}{c}72.586 \pm \\
0.451\end{array}$ & $\begin{array}{c}74.663 \pm \\
0.446\end{array}$ & $\begin{array}{l}77.550 \pm \\
0.463\end{array}$ & $\begin{array}{c}80.586 \pm \\
0.451\end{array}$ \\
\hline $\begin{array}{l}\text { Aqueous } \\
\text { ethanol } \\
\text { extract }\end{array}$ & $\begin{array}{l}60.28 \pm \\
2.356^{\mathrm{ns}}\end{array}$ & $64.61 \pm 1.84^{\mathrm{ns}}$ & $\begin{array}{c}67.433 \pm \\
2.225^{\text {ns }}\end{array}$ & $\begin{array}{c}79.163 \pm \\
0.80^{*}\end{array}$ & $\begin{array}{l}82.373 \pm \\
1.061^{*}\end{array}$ & $\begin{array}{c}84.780 \pm \\
0.400^{*}\end{array}$ & $\begin{array}{c}87.506 \pm \\
1.926^{*}\end{array}$ & $\begin{array}{l}95.00 \pm \\
0.577^{* * *}\end{array}$ \\
\hline $\begin{array}{l}\text { n-Butanol } \\
\text { Fraction }\end{array}$ & $\begin{array}{c}35.623 \pm \\
4.06^{* * *}\end{array}$ & $\begin{array}{l}40.126 \pm \\
3.383^{* * *}\end{array}$ & $\begin{array}{l}45.260 \pm \\
3.495^{* * *}\end{array}$ & $\begin{array}{c}55.993 \pm \\
5.350^{* *}\end{array}$ & $\begin{array}{l}58.380 \pm \\
2.839^{* * *}\end{array}$ & $\begin{array}{c}61.113 \pm \\
2.627^{* *}\end{array}$ & $\begin{array}{l}65.510 \pm \\
2.25^{* *}\end{array}$ & $\begin{array}{c}69.233 \pm \\
2.126^{*}\end{array}$ \\
\hline $\begin{array}{l}\text { Aqueous } \\
\text { Fraction }\end{array}$ & $\begin{array}{c}45.516 \pm \\
0.803^{* * *}\end{array}$ & $\begin{array}{c}50.776 \pm \\
4.364^{* * *}\end{array}$ & $\begin{array}{c}56.776 \pm \\
4.364^{*}\end{array}$ & $\begin{array}{c}80.390 \pm \\
1.807^{*}\end{array}$ & $\begin{array}{c}86.176 \pm \\
1.958^{* *}\end{array}$ & $\begin{array}{c}85.246 \pm \\
2.407^{*}\end{array}$ & $\begin{array}{c}87.846 \pm \\
3.651^{*}\end{array}$ & $\begin{array}{c}92.840 \pm \\
2.603^{* *}\end{array}$ \\
\hline
\end{tabular}

Values expressed as mean $\pm \operatorname{SEM}(\mathrm{n}=3), * * * \mathrm{p}<0.001,{ }^{* *} \mathrm{p}<0.01,{ }^{*} \mathrm{p}<0.05, \mathrm{~ns}=$ non-significant as compared to Standard control done by Two way ANOVA followed by Bonferroni post test

TABLE II - Effect of Ribes alpestre on inhibition of protein (Egg albumin) denaturation

\begin{tabular}{lcccccccc}
\hline \multicolumn{7}{c}{$\begin{array}{c}\text { Percentage protection against protein denaturation } \\
\text { Concentration }(\mathbf{u g} / \mathbf{m L})\end{array}$} \\
$\begin{array}{l}\text { Treatment } \\
\text { Groups }\end{array}$ & $\mathbf{5 0}$ & $\mathbf{1 0 0}$ & $\mathbf{2 0 0}$ & $\mathbf{4 0 0}$ & $\mathbf{8 0 0}$ & $\mathbf{1 6 0 0}$ & $\mathbf{3 2 0 0}$ & $\mathbf{6 4 0 0}$ \\
\hline Diclofenac & $66.67 \pm$ & $67.36 \pm$ & $69.44 \pm$ & $77.07 \pm$ & $88.14 \pm$ & $182.64 \pm$ & $370.83 \pm$ & $717.36 \pm$ \\
sodium & 5.24 & 4.22 & 1.386 & 2.40 & 1.88 & 2.50 & 2.08 & 5.42 \\
Aqueous & $88.890 \pm$ & $127.08 \pm$ & $190.97 \pm$ & $458.33 \pm$ & $1122.92 \pm$ & $1522.92 \pm$ & $2022.91 \pm$ & $3653.47 \pm$ \\
ethanol & $4.862^{\text {ns }}$ & $8.67^{\text {ns }}$ & $17.27^{\text {ns }}$ & $15.91^{* *}$ & $65.84^{* * *}$ & $136.40^{* * *}$ & $124.27^{* * *}$ & $200.92^{* * *}$ \\
extract & & & & & & & & \\
n-Butanol & $37.50 \pm$ & $50.69 \pm$ & $65.97 \pm$ & $95.83 \pm$ & $213.19 \pm$ & $298.50 \pm$ & $703.22 \pm$ & $1484.03 \pm$ \\
Fraction & $2.08^{\text {ns }}$ & $1.386^{\text {ns }}$ & $4.22^{\text {ns }}$ & $4.34^{\text {ns }}$ & $20.14^{\text {ns }}$ & $1.50^{\text {ns }}$ & $74.70^{* *}$ & $211.17^{* * *}$ \\
Aqueous & $140.28 \pm$ & $171.53 \pm$ & $400.00 \pm$ & $818.05 \pm$ & $1625.00 \pm$ & $1977.77 \pm$ & $2204.17 \pm$ & $3563.19 \pm$ \\
Fraction & $5.42^{\text {ns }}$ & $4.86^{\text {ns }}$ & $14.18^{* *}$ & $19.59^{* * *}$ & $40.74^{* * *}$ & $25.52^{* * *}$ & $49.14^{* * *}$ & $128.48^{* * *}$ \\
\hline
\end{tabular}

Data represented as mean $\pm \operatorname{SEM}(\mathrm{n}=3), * * * \mathrm{p}<0.001, * * \mathrm{p}<0.01, * \mathrm{p}<0.05, \mathrm{~ns}=$ non-significant as compared to Standard control done by Two way ANOVA followed by Bonferroni posttest.

albumin at highest concentration. Whereas, butanol and aqueous fractions showed noteworthy $1484.03 \%$ and $3563.19 \%$ barricade of egg albumin denudation in that order. Diclofenac sodium demonstrated $717.36 \%$ blockade of pathological modification of egg albumin. Results have divulged that plant extract together with aqueous fraction more significantly avert abnormal protein alteration than aspirin and diclofenac sodium.

Current findings have showed that hydroethanolic extract notably prevented heat and hypotonicity induced hemolysis in dose dependent manner. Diclofenac sodium showed (20.30-70.50\%) stabilization of red blood cell membrane at $(50-6400 \mathrm{ug} / \mathrm{mL})$. Whereas, aqueous ethanol extract demonstrated 69.11-91.29\% RBC membrane stabilization against lysis. Likewise, butanol and aqueous fraction exhibited (44.45-65.73\%) and (60.38-89.62\%) erythrocyte membrane stability against membrane rupture at $50-6400 \mathrm{ug} / \mathrm{mL}$ concentration respectively.

In formaldehyde induced rat paw edema Ribes alpestre showed significant and dose dependent $(50,100$ and $200 \mathrm{mg} / \mathrm{kg}$ ) decrease in paw swelling. Aqueous ethanol extract notably (73.49\%) decreased paw edema along with $72.38 \%$ reduction in paw diameter at $200 \mathrm{mg} / \mathrm{kg}$ dose. Similarly butanol fraction showed $66.42 \%$ decrease in inflammatory exudate with $54.90 \%$ decline in paw thickness at highest dose. Likewise aqueous fraction illustrated $68.87 \%$ decrease in paw inflammation and $66.33 \%$ decline in paw diameter. Piroxicam showed 
$71.89 \%$ inhibition of paw swelling alongwith $70.69 \%$ attenuation of paw thickness.

\section{DISCUSSION}

Present investigation explicated the antiarthritic activity of aqueous ethanolic extract together with butanolic and aqueous fractions of Ribes alpestre Decne using both in vitro assays as well as formaldehyde induced arthritis in rats. As, rheumatoid arthritis is a chronic progressive autoimmune disease involving various joints causing pain, inflammation, cartilage and bone deterioration resulting in functional disability. Notwithstanding the availability of different classes of drugs, arthritic patients have to suffer from physical immobility as well as other allied complications and also experience number of undesirable effects. Hence the use of complementary and alternative therapies including herbal products is now increasing day by day owing to their safety, efficacy and cost effectiveness.

It has been illustrated that pathological alteration of tissue proteins through changes in hydrophobic, electrostatic, hydrogen and disulphide bonding leads to generation of autoantigens thus, causing various inflammatory arthritic diseases (Alamgeer et al., 2017; Gupta et al., 2013). It has been reported that inhibition of denaturation of BSA at pathological $\mathrm{pH}$ (6.2-6.5) was accountable for anti-inflammtory action of various NSAIDs including salicylic acid, diclofenac sodium, flufenamic acid and indomethacin (Alamgeer, Uttra, Hasan, 2017). Ethanolic extract as well as both fractions of Ribes alpestre exhibited remarkable efficacy against protein (egg albumin and bovine serum albumin) denaturation as shown in (Table I, II). Cellular infiltration is key component of inflammation and leukocytes release lysosomal contents including bactericidal enzymes and proteases that exacerbate inflammatory response and tissue damage. Moreover, erythrocyte membrane is akin to that of lysosomal membrane and maintaining the integrity of lysosomal membrane against heat and hypotonicity induced lysis recommends another possible mechanism of action in arthritis. Seeing that, hypotonic saline causes cell rupture and damage to lysosomal membrane owing to massive accrual of fluid thus inciting phospholipase A2 discharge that hydrolyse membrane phospholipids producing a range of inflammatory intermediaries. Therefore, membrane stabilization prevents cell rupture and discharge of cellular contents which eventually assuage tissue damage. Since proteins (ion channels) contribute to the physical integrity of biological membranes and in the regulation of cell homeostasis by controlling movement of water and ions (sodium and potassium). From the present results aqueous ethanolic extract and its fractions exhibited noteworthy concentration dependent stabilization of RBC membrane as given in (Table III). Direct protective intercalation of phytoconstituents with membrane proteins, seems to be the probable mechanism of action in membrane stabilization even though exact underlying mechanism is not known (Okoli et al., 2008).

In general, formaldehyde induced arthritis is used for investigating anti-inflammatory and immunomodulatory potential of newer agents (Ruth, Olaide, Oluwatoyn, 2014). In formaldehyde induced arthritis Ribes alpestre substantially alleviated paw swelling along with soft tissue thickening in dose dependent manner as summarized in (Table IV and V). Previous studies have acknowledged

TABLE III - Percent stabilization of Human red blood cell membrane by Ribes alpestre

\begin{tabular}{|c|c|c|c|c|c|c|c|c|}
\hline \multicolumn{9}{|c|}{$\begin{array}{l}\text { Percentage protection against membrane lysis } \\
\text { Concentration }(\mathrm{ug} / \mathrm{mL})\end{array}$} \\
\hline $\begin{array}{l}\text { Treatment } \\
\text { Groups }\end{array}$ & 50 & 100 & 200 & 400 & 800 & 1600 & 3200 & 6400 \\
\hline $\begin{array}{l}\text { Diclofenac } \\
\text { sodium }\end{array}$ & $\begin{array}{c}20.30 \pm \\
0.144\end{array}$ & $\begin{array}{c}21.79 \pm \\
0.15\end{array}$ & $\begin{array}{c}22.61 \pm \\
0.17\end{array}$ & $\begin{array}{c}24.56 \pm \\
0.17\end{array}$ & $\begin{array}{c}26.70 \pm \\
0.14\end{array}$ & $\begin{array}{c}31.36 \pm \\
0.15\end{array}$ & $\begin{array}{c}49.54 \pm \\
0.10\end{array}$ & $\begin{array}{c}70.50 \pm \\
0.12\end{array}$ \\
\hline $\begin{array}{l}\text { n-Butanol } \\
\text { Fraction }\end{array}$ & $\begin{array}{c}44.45 \pm \\
1.50^{* * *}\end{array}$ & $\begin{array}{c}48.90 \pm \\
0.84^{* * *}\end{array}$ & $\begin{array}{c}52.86 \pm \\
1.76^{* * *}\end{array}$ & $\begin{array}{l}57.30 \pm \\
2.55^{* * *}\end{array}$ & $\begin{array}{l}59.21 \pm \\
2.95^{* * *}\end{array}$ & $\begin{array}{c}62.97 \pm \\
0.19^{* * * *}\end{array}$ & $\begin{array}{c}64.77 \pm \\
0.23^{* * *}\end{array}$ & $\begin{array}{r}65.73 \pm \\
1.66^{\mathrm{ns}}\end{array}$ \\
\hline $\begin{array}{l}\text { Aqueous } \\
\text { Fraction }\end{array}$ & $\begin{array}{c}60.38 \pm \\
2.51^{* * *}\end{array}$ & $\begin{array}{c}65.18 \pm \\
6.25^{* * *}\end{array}$ & $\begin{array}{c}73.83 \pm \\
0.73^{* * *}\end{array}$ & $\begin{array}{c}77.15 \pm \\
0.36^{* * *}\end{array}$ & $\begin{array}{c}80.73 \pm \\
0.09^{* * * *}\end{array}$ & $\begin{array}{c}84.33 \pm \\
0.27^{* * * *}\end{array}$ & $\begin{array}{c}86.54 \pm \\
0.09^{* * *}\end{array}$ & $\begin{array}{c}89.62 \pm \\
0.07^{* * *}\end{array}$ \\
\hline
\end{tabular}

Results expressed as mean \pm SEM $(n=3)$, done by Two way ANOVA followed by Bonferroni posttest. Where ${ }^{* *} p<0.001, n s=$ non-significant as compared to Standard control. 
that paw and ankle joint swelling in arthritic rats might be on account of edema of joint ligament and capsule subsequent to formaldehyde injection (Dheeba et al., 2012). Formaldehyde produce distinct biphasic algesia an early neurogenic pain after that tissue mediated response. It is noteworthy to proclaim that ethanolic extract and fractions of Ribes alpestre have the potential of acting both centrally as well peripherally in alleviating biphasic pain possibly by inhibiting both cyclooxygenase as well as lipoxygenase pathway (Choudhary et al., 2014; Kaithwas et al., 2012). Previously, it has been accrediated that formaldehyde denatures proteins at the site of injection infuriating immunological reaction against such degraded protein products (Kumar et al., 2016) and crude extract/fractions of Ribes alpestre possess efficacy against tissue protein degradation as revealed in in-vitro assay. Moreover, previously it has been recognized that formaldehyde also causes synovial fibroblast overgrowth accountable for synovial hyperplasia, pannus formation, discharge of various factors that sustain inflammation, neovascularization, cartilage and joint tissue abolition
(Saleem et al., 2011). Nevertheless, formaldehyde induced arthritis has some limitations that it is self-limiting and does not stimulate cell-mediated immunity (Nair, Singh, Gupta, 2012). Thus, Ribes alpestre has antiarthritic efficacy as declared from results of in vitro assays as well as in vivo formaldehyde induced arthritis.

Earlier studies have documented that berries belonging to Ribes genus and grossulariaceae family are endowed with polyphenolic constituents including, flavonols, ellagitannins, anthocyanins, hydroxybenzoic, hydroxycinnamic acid derivatives as well as flavan-3-ols and proanthocyanidins (Maatta, Eldin, Torronen, 2003). Moreover, it has been studied that Ribes nigrum possess potent antioxidant and anti-inflammtory activity owing to the presence of phenolic compounds accountable for its wide use in the treatment of inflammatory disorders such as rheumatic diseases.

Furthermore, proanthocyanidins contained in blackcurrant leaves impede accumulation of circulatory leukocytes, associated with a decrease in pro-inflammatory cytokines such as TNF- $\alpha$, IL- $1 \beta$, NO and CINC-1

TABLE IV - Effect of Ribes alpestre on Paw volume in Formaldehyde induced arthritis

\begin{tabular}{|c|c|c|c|c|c|}
\hline Treatment groups & $2^{\text {nd }}$ day & $4^{\text {th }}$ day & $6^{\text {th }}$ day & $8^{\text {th }}$ day & $10^{\text {th }}$ day \\
\hline \multicolumn{6}{|c|}{ Increase in paw volume $(\mathrm{mL})$} \\
\hline $\begin{array}{l}\text { Arthritic control } \\
(3 \mathrm{~mL} / \mathrm{kg})\end{array}$ & $1.474 \pm 0.044$ & $1.872 \pm 0.025$ & $2.000 \pm 0.014$ & $2.032 \pm 0.017$ & $2.120 \pm 0.029$ \\
\hline $\begin{array}{l}\text { Piroxicam } \\
(10 \mathrm{mg} / \mathrm{kg})\end{array}$ & $\begin{array}{c}1.196 \pm 0.069^{* *} \\
(18.86 \%)\end{array}$ & $\begin{array}{c}1.044 \pm 0.069^{* * *} \\
(44.23 \%)\end{array}$ & $\begin{array}{c}0.852 \pm 0.068^{* * *} \\
(57.4 \%)\end{array}$ & $\begin{array}{l}0.682 \pm 0.049^{* * *} \\
\quad(66.44 \%)\end{array}$ & $\begin{array}{c}0.596 \pm 0.042^{* * *} \\
\quad(71.89 \%)\end{array}$ \\
\hline $\begin{array}{l}\text { Aqueous ethanol } \\
\text { extract }(50 \mathrm{mg} / \mathrm{kg})\end{array}$ & $\begin{array}{l}1.248 \pm 0.011^{* * *} \\
\quad(15.33 \%)\end{array}$ & $\begin{array}{c}1.362 \pm 0.015^{* * *} \\
(27.24 \%)\end{array}$ & $\begin{array}{c}1.300 \pm 0.008^{* * *} \\
(35 \%)\end{array}$ & $\begin{array}{l}1.222 \pm 0.011^{* * *} \\
\quad(39.96 \%)\end{array}$ & $\begin{array}{c}1.106 \pm 0.007^{* * *} \\
(47.83 \%)\end{array}$ \\
\hline $\begin{array}{l}\text { Aqueous ethanol } \\
\text { extract }(100 \mathrm{mg} / \mathrm{kg})\end{array}$ & $\begin{array}{l}1.100 \pm 0.011^{* * *} \\
\quad(25.37 \%)\end{array}$ & $\begin{array}{c}1.204 \pm 0.029^{* * *} \\
(35.68 \%)\end{array}$ & $\begin{array}{c}1.150 \pm 0.029^{* * *} \\
(42.5 \%)\end{array}$ & $\begin{array}{c}1.080 \pm 0.028^{* * *} \\
(46.85 \%)\end{array}$ & $\begin{array}{c}1.000 \pm 0.028^{* * *} \\
\quad(52.83 \%)\end{array}$ \\
\hline $\begin{array}{l}\text { Aqueous ethanol } \\
\text { extract }(200 \mathrm{mg} / \mathrm{kg})\end{array}$ & $\begin{array}{l}0.998 \pm 0.066^{* * *} \\
\quad(32.29 \%)\end{array}$ & $\begin{array}{c}1.044 \pm 0.102^{* * *} \\
\quad(44.23 \%)\end{array}$ & $\begin{array}{c}0.786 \pm 0.046^{* * *} \\
\quad(60.7 \%)\end{array}$ & $\begin{array}{l}0.692 \pm 0.040^{* * *} \\
\quad(65.94 \%)\end{array}$ & $\begin{array}{c}0.562 \pm 0.010^{* * *} \\
\quad(73.49 \%)\end{array}$ \\
\hline $\begin{array}{l}\text { Butanol fraction } \\
(50 \mathrm{mg} / \mathrm{kg})\end{array}$ & $\begin{array}{c}1.306 \pm 0.043^{\mathrm{ns}} \\
(11.39 \%)\end{array}$ & $\begin{array}{c}1.544 \pm 0.048^{* * *} \\
\quad(17.52 \%)\end{array}$ & $\begin{array}{c}1.450 \pm 0.064^{* * *} \\
(27.5 \%)\end{array}$ & $\begin{array}{c}1.302 \pm 0.058^{* * *} \\
(35.93 \%)\end{array}$ & $\begin{array}{c}1.220 \pm 0.051^{* * *} \\
(42.45 \%)\end{array}$ \\
\hline $\begin{array}{l}\text { Butanol fraction } \\
(100 \mathrm{mg} / \mathrm{kg})\end{array}$ & $\begin{array}{c}1.224 \pm 0.045^{*} \\
(16.96 \%)\end{array}$ & $\begin{array}{c}1.468 \pm 0.067^{* * *} \\
(21.58 \%)\end{array}$ & $\begin{array}{c}1.396 \pm 0.053^{* * *} \\
(30.2 \%)\end{array}$ & $\begin{array}{c}1.326 \pm 0.042^{* * *} \\
\quad(34.74 \%)\end{array}$ & $\begin{array}{c}1.198 \pm 0.035^{* * *} \\
(43.49 \%)\end{array}$ \\
\hline $\begin{array}{l}\text { Butanol fraction } \\
(200 \mathrm{mg} / \mathrm{kg})\end{array}$ & $\begin{array}{c}1.214 \pm 0.101^{* *} \\
(17.64 \%)\end{array}$ & $\begin{array}{l}1.344 \pm 0.051^{* * *} \\
\quad(28.21 \%)\end{array}$ & $\begin{array}{c}1.084 \pm 0.089^{* * *} \\
(45.8 \%)\end{array}$ & $\begin{array}{l}0.872 \pm 0.042^{* * *} \\
\quad(57.09 \%)\end{array}$ & $\begin{array}{c}0.712 \pm 0.039^{* * *} \\
\quad(66.42 \%)\end{array}$ \\
\hline $\begin{array}{l}\text { Aqueous Fraction } \\
(50 \mathrm{mg} / \mathrm{kg})\end{array}$ & $\begin{array}{c}1.254 \pm 0.062^{\mathrm{ns}} \\
(14.93 \%)\end{array}$ & $\begin{array}{l}1.426 \pm 0.100^{* * *} \\
(23.82 \%)\end{array}$ & $\begin{array}{c}1.350 \pm 0.078^{* * *} \\
(32.5 \%)\end{array}$ & $\begin{array}{c}1.288 \pm 0.069^{* * *} \\
(36.61 \%)\end{array}$ & $\begin{array}{c}1.208 \pm 0.086^{* * *} \\
(43.02 \%)\end{array}$ \\
\hline $\begin{array}{l}\text { Aqueous Fraction } \\
(100 \mathrm{mg} / \mathrm{kg})\end{array}$ & $\begin{array}{l}1.170 \pm 0.065^{*} \\
(20.62 \%)\end{array}$ & $\begin{array}{c}1.382 \pm 0.104^{* * *} \\
(26.18 \%)\end{array}$ & $\begin{array}{c}1.320 \pm 0.081^{* * *} \\
(34 \%)\end{array}$ & $\begin{array}{c}1.250 \pm 0.106^{* * *} \\
(38.48 \%)\end{array}$ & $\begin{array}{c}1.166 \pm 0.114^{* * *} \\
(45 \%)\end{array}$ \\
\hline $\begin{array}{l}\text { Aqueous Fraction } \\
(200 \mathrm{mg} / \mathrm{kg})\end{array}$ & $\begin{array}{c}1.150 \pm 0.079^{* *} \\
(21.98 \%) \\
\end{array}$ & $\begin{array}{c}1.278 \pm 0.043^{* * *} \\
(31.73 \%)\end{array}$ & $\begin{array}{c}0.870 \pm 0.043^{* * *} \\
(56.5 \%)\end{array}$ & $\begin{array}{c}0.788 \pm 0.070^{* * *} \\
(61.22 \%)\end{array}$ & $\begin{array}{c}0.660 \pm 0.062^{* * *} \\
(68.87 \%)\end{array}$ \\
\hline
\end{tabular}

Values are expressed as mean \pm SEM $(n=5)$, by Two way ANOVA followed by Bonferroni posttest used and $\mathrm{p}<0.05$ was considered as significant as compared to arthritic control. Where ${ }^{* * *} \mathrm{p}<0.001,{ }^{* *} \mathrm{p}<0.01,{ }^{*} \mathrm{p}<0.05$, ns $=$ non-significant 
Evaluation of in vitro and in vivo therapeutic efficacy of Ribes alpestre Decne in Rheumatoid arthritis

TABLE V - Effect of Ribes alpestre on Paw diameter in formaldehyde induced arthritis

\begin{tabular}{|c|c|c|c|c|c|}
\hline Treatment groups & $2^{\text {nd }}$ day & $4^{\text {th }}$ day & $6^{\text {th }}$ day & $8^{\text {th }}$ day & $10^{\text {th }}$ day \\
\hline \multicolumn{6}{|c|}{ Increase in paw diameter $(\mathrm{mm})$} \\
\hline $\begin{array}{l}\text { Arthritic control } \\
(3 \mathrm{~mL} / \mathrm{kg})\end{array}$ & $6.436 \pm 0.098$ & $8.454 \pm 0.023$ & $10.578 \pm 0.024$ & $11.11 \pm 0.026$ & $12.772 \pm 0.128$ \\
\hline $\begin{array}{l}\text { Piroxicam } \\
(10 \mathrm{mg} / \mathrm{kg})\end{array}$ & $\begin{array}{l}4.800 \pm 0.198^{* * *} \\
\quad(25.42 \%)\end{array}$ & $\begin{array}{l}5.742 \pm 0.303^{* * *} \\
\quad(32.08 \%)\end{array}$ & $\begin{array}{l}5.282 \pm 0.180^{* * *} \\
\quad(50.07 \%)\end{array}$ & $\begin{array}{l}4.102 \pm 0.094^{* * *} \\
\quad(60.08 \%)\end{array}$ & $\begin{array}{l}3.744 \pm 0.133^{* * *} \\
\quad(70.69 \%)\end{array}$ \\
\hline $\begin{array}{l}\text { Aqueous ethanol } \\
\text { extract }(50 \mathrm{mg} / \mathrm{kg})\end{array}$ & $\begin{array}{c}5.874 \pm 0.097^{*} \\
(8.73 \%)\end{array}$ & $\begin{array}{l}7.226 \pm 0.078^{* * *} \\
\quad(14.52 \%)\end{array}$ & $\begin{array}{c}7.252 \pm 0.097^{* * *} \\
\quad(31.44 \%)\end{array}$ & $\begin{array}{c}7.222 \pm 0.106^{* * *} \\
(35 \%)\end{array}$ & $\begin{array}{c}7.080 \pm 0.108^{* * *} \\
\quad(44.56 \%)\end{array}$ \\
\hline $\begin{array}{l}\text { Aqueous ethanol } \\
\text { extract }(100 \mathrm{mg} / \mathrm{kg})\end{array}$ & $\begin{array}{l}5.228 \pm 0.110^{* * *} \\
\quad(18.76 \%)\end{array}$ & $\begin{array}{l}5.810 \pm 0.183^{* * *} \\
\quad(31.27 \%)\end{array}$ & $\begin{array}{l}5.734 \pm 0.188^{* * *} \\
(45.79 \%)\end{array}$ & $\begin{array}{l}5.644 \pm 0.177^{* * *} \\
(49.20 \%)\end{array}$ & $\begin{array}{l}5.606 \pm 0.156^{* * *} \\
\quad(56.11 \%)\end{array}$ \\
\hline $\begin{array}{l}\text { Aqueous ethanol } \\
\text { extract }(200 \mathrm{mg} / \mathrm{kg})\end{array}$ & $\begin{array}{l}4.812 \pm 0.134^{* * *} \\
\quad(25.23 \%)\end{array}$ & $\begin{array}{c}4.808 \pm 0.161^{* * *} \\
\quad(43.13 \%)\end{array}$ & $\begin{array}{l}4.242 \pm 0.075^{* * *} \\
\quad(59.89 \%)\end{array}$ & $\begin{array}{l}3.866 \pm 0.122^{* * *} \\
\quad(65.21 \%)\end{array}$ & $\begin{array}{l}3.528 \pm 0.033^{* * *} \\
\quad(72.38 \%)\end{array}$ \\
\hline $\begin{array}{l}\text { Butanol fraction } \\
(50 \mathrm{mg} / \mathrm{kg})\end{array}$ & $\begin{array}{l}6.122 \pm 0.114^{\mathrm{ns}} \\
\quad(4.88 \%)\end{array}$ & $\begin{array}{l}8.216 \pm 0.272^{\mathrm{ns}} \\
\quad(2.82 \%)\end{array}$ & $\begin{array}{l}8.05 \pm 0.290^{* * *} \\
(23.89 \%)\end{array}$ & $\begin{array}{l}7.584 \pm 0.328^{* * *} \\
(31.74 \%)\end{array}$ & $\begin{array}{l}7.442 \pm 0.334^{* * *} \\
\quad(41.73 \%)\end{array}$ \\
\hline $\begin{array}{l}\text { Butanol fraction } \\
(100 \mathrm{mg} / \mathrm{kg})\end{array}$ & $\begin{array}{l}5.70 \pm 0.154^{\mathrm{ns}} \\
(3.76 \%)\end{array}$ & $\begin{array}{c}7.422 \pm 0.189^{* *} \\
(12.21 \%)\end{array}$ & $\begin{array}{c}6.872 \pm 0.293^{* * *} \\
\quad(35.03 \%)\end{array}$ & $\begin{array}{l}6.144 \pm 0.353^{* * *} \\
\quad(44.70 \%)\end{array}$ & $\begin{array}{l}5.930 \pm 0.369^{* * *} \\
\quad(53.57 \%)\end{array}$ \\
\hline $\begin{array}{l}\text { Butanol fraction } \\
(200 \mathrm{mg} / \mathrm{kg})\end{array}$ & $\begin{array}{l}5.504 \pm 0.131^{*} \\
(14.48 \%)\end{array}$ & $\begin{array}{c}6.422 \pm 0.102^{* * *} \\
\quad(24.04 \%)\end{array}$ & $\begin{array}{c}6.550 \pm 0.119^{* * *} \\
(22.52 \%)\end{array}$ & $\begin{array}{c}6.104 \pm 0.154^{* * *} \\
\quad(45.06 \%)\end{array}$ & $\begin{array}{l}5.760 \pm 0.159^{* * *} \\
\quad(54.90 \%)\end{array}$ \\
\hline $\begin{array}{l}\text { Aqueous fraction } \\
(50 \mathrm{mg} / \mathrm{kg})\end{array}$ & $\begin{array}{c}6.086 \pm 0.139^{\mathrm{ns}} \\
(5.44 \%)\end{array}$ & $\begin{array}{c}7.092 \pm 0.144^{*} \\
(16.11 \%)\end{array}$ & $\begin{array}{l}6.924 \pm 0.083^{* * *} \\
\quad(34.54 \%)\end{array}$ & $\begin{array}{c}7.002 \pm 0.164^{* * *} \\
(36.98 \%)\end{array}$ & $\begin{array}{c}6.178 \pm 1.513^{* * *} \\
\quad(51.63 \%)\end{array}$ \\
\hline $\begin{array}{l}\text { Aqueous fraction } \\
(100 \mathrm{mg} / \mathrm{kg})\end{array}$ & $\begin{array}{l}5.248 \pm 0.068^{\mathrm{ns}} \\
\quad(18.46 \%)\end{array}$ & $\begin{array}{l}6.410 \pm 0.154^{* * *} \\
\quad(24.18 \%)\end{array}$ & $\begin{array}{c}6.506 \pm 0.112^{* * *} \\
\quad(38.49 \%)\end{array}$ & $\begin{array}{l}5.994 \pm 0.064^{* * *} \\
\quad(46.05 \%)\end{array}$ & $\begin{array}{l}5.696 \pm 0.081^{* * *} \\
\quad(55.40 \%)\end{array}$ \\
\hline $\begin{array}{l}\text { Aqueous fraction } \\
(200 \mathrm{mg} / \mathrm{kg})\end{array}$ & $\begin{array}{c}4.940 \pm 0.094^{* *} \\
(23.24 \%)\end{array}$ & $\begin{array}{c}5.570 \pm 0.155^{* * *} \\
\quad(34.11 \%)\end{array}$ & $\begin{array}{c}5.600 \pm 0.173^{* * *} \\
(47.06 \%)\end{array}$ & $\begin{array}{c}4.860 \pm 0.098^{* * *} \\
(56.26 \%)\end{array}$ & $\begin{array}{c}4.300 \pm 0.116^{* * *} \\
(66.33 \%)\end{array}$ \\
\hline
\end{tabular}

Values are expressed as mean \pm SEM $(n=5)$, done by Two way ANOVA followed by Bonferroni posttest and $\mathrm{p}<0.05$ was considered as significant as compared to arthritic control. Where ${ }^{* * *} \mathrm{p}<0.001,{ }^{*} \mathrm{p}<0.01,{ }^{*} \mathrm{p}<0.05$, ns $=$ non-significant

(Butnariu, 2014; Tabart et al., 2012). In consequence, being the member of same family and genus antiarthritic potential of Ribes alpestre might be owing to the presence of valuable phenolic compounds. However, its plausible mechanism of action and responsible phytochemicals in treatment of rheumatoid arthritis is under deliberation through complete Freunds adjuvant (CFA) induced arthritis.

In brief Ribes alpestre possess substantial antiarthritic activity as demonstrated by in vitro assays as well as in vivo formaldehyde induced arthritis. Further investigations on phytochemistry to identify responsible constituents and possible mechanisms of antiarthritic action in rheumatoid arthritis are undergoing.

\section{REFERENCES}

Alamgeer, Niazi SG, Uttra AM, Qaiser MN, Ahsan H. Appraisal of anti-arthritic and nephroprotective potential of Cuscuta reflexa. Pharm Biol. 2017;55(1):792-798.
Alamgeer, Uttra AM, Hasan UH. Anti-arthritic activity of aqueous-methanolic extract and various fractions of Berberis orthobotrys Bien ex Aitch. BMC Complement Altern Med. 2017;17(371):1-16.

Alamgeer, Hasan UH, Uttra AM, Rasool S. Evaluation of in vitro and in vivo anti-arthritic potential of Berberis calliobotrys. Bangladesh J Pharmacol. 2015;10(4):807-19.

Abbas Q, Khan SW, Khatoon S, Hussain SA, Hassan SN, Hussain A, Qureshi R, Hussain I. Floristic biodiversity and traditional uses of medicinal plants of Haramosh Valley Central Karakoram National Park of Gilgit district, Gilgit-Baltistan. Pak J Bio Env Sci. 2014;5(6):75-86.

Butnariu M. Detection of the polyphenolic components in Ribes nigrum L. Ann Agric Environ Med. 2014; 21(1):11-14. 
Choudhary M, Kumar V, Gupta P, Singh S. Investigation of antiarthritic potential of Plumeria alba L.Leaves in acute and chronic models of arthritis. BioMed Res Int. 2014;2014:474616.

Dheeba B, Sampathkumar P, Kannan M, Vaishnavi E, Maragatham. Therapeutic Efficacy of Spirulina In the treatment of formaldehyde induced rheumatoid arthritis in swiss albino mice. Biosci Biotechnol Res Asia. 2012;9(1):321-326.

Gupta SK, Gupta A, Gupta AK, Pakash D, Vedpal. In vitro anti arthritic activity of ethanolic extract of Callicarpa macrophylla flower. Int Res J Pharm. 2013; 4(3):160-62.

Kay J, Calabrese L. The role of interleukin-1 in the pathogenesis of rheumatoid arthritis. Rheumatol. 2004;43(Suppl 3):iii2-iii9.

Kumar R, Nair V, Gupta YK, Singh S, Arunraja S. Berberis aristata Ameliorates adjuvant-induced arthritis by inhibition of NF- $\kappa \mathrm{B}$ and activating nuclear Factor-E2-related Factor 2/ hem Oxygenase (HO)-1 signaling pathway. Immunol Invest. 2016;45(6):473-89.

Khan B, Abdukadir A, Qureshi R, Mustafa G. Medicinal uses of plants by the inhabitants of Khunjerab National park, Gilgit, Pakistan. Pak J Bot. 2011;43(5):2301-2310.

Kaithwas G, Gautam R, Jachak SM, Saklani A. Antiarthritic effects of Ajuga bracteosa Wall ex Benth. in acute and chronic models of arthritis in albino rats. Asian Pac J Trop Biomed. 2012;2(3):185-188.

Maatta KR, Eldin AK, Torronen AR. High-Performance Liquid Chromatography (HPLC) analysis of phenolic compounds in berries with diode array and electrospray ionization Mass Spectrometric (MS) detection: Ribes species. J Agric Food Chem. 2003;51(23):6736-6744.
Nwachukwu CU, Umeh CN, Kalu IG. Identification and traditional uses of some common medicinal plants in ezinihitte mbaise L.G.A., Of Imo State, Nigeria. Rep Opin. 2010;2(6):1-8.

Nair V, Singh S, Gupta YK. Evaluation of disease modifying activity of Coriandrum sativum in experimental models. Ind J Med Res. 2012;135(2):240-245.

Okoli CO, Akah PA, Onuoha NJ, Okoye TC, Nwoye AC, Nworu CS. Acanthus montanus: An experimental evaluation of the antimicrobial, anti-inflammatory and immunological properties of a traditional remedy for furuncles. BMC Complem Altern Med. 2008;8:27.

Ruth AF, Olaide AO, Oluwatoyin SM. The aqueous root extract of Aristolochia ringens (Vahl.) Aristolochiaceae inhibits chemically-induced inflammation in rodents. Pak J Pharm Sci. 2014;27(6):1885-1889.

Saleem TSM, Basha SD, Mahesh G, Rani PVS. Anagesic, antipyretic ad antiinfammatory activity of dietary sesame oil in experimental animal models. Pharmacologia. 2011;2(6):172177.

Tabart J, Franck T, Kevers C, Pincemail J, Serteyn D, Defraigne $\mathrm{J}$, et al. Antioxidant and anti-inflammatory activities of Ribes nigrum extracts. Food Chem. 2012;131(4):1116-1122.

Received for publication on $21^{\text {st }}$ December 2017 Accepted for publication on $04^{\text {th }}$ May 2018 